\title{
Millennial Entrepreneur Ecosystem Based on Digital (Digital Entrepreneurship) in Pandemic Covid 19 in Makassar City
}

\author{
Muhammad Azis ${ }^{1}$, Muhammad Alfa Sikar ${ }^{2}$, Fajriani Azis ${ }^{3, *}$, Nurjannah $^{4}$ \\ ${ }^{1}$ Department of Accounting Education, Faculty of Economics, Universitas Negeri Makassar, Makassar, Indonesia \\ ${ }^{2}$ Department of Entrepreneurship, Faculty of Economics, Universitas Negeri Makassar, Makassar, Indonesia \\ ${ }^{3}$ Department of Accounting Education, Faculty of Economics, Universitas Negeri Makassar, Makassar, Indonesia \\ ${ }^{4}$ Department of Economic Education, Faculty of Economics, Universitas Negeri Makassar, Makassar, Indonesia \\ *Corresponding author.Email: fajrianiazis@unm.ac.id
}

\begin{abstract}
During the COVID-19 pandemic, digital-based millennial entrepreneurship is a digital entrepreneurship ecosystem that pays attention to the development of technology, information and communication which is used as a model for changing conventional businesses into digital platforms. The research method used is literature study and documentation. Based on a factor analysis of the digital-based millennial entrepreneurship ecosystem, it was found that digital utilization is low due to policies that cannot be exceeded by the explicit and implicit social norms of the digital generation in the city of Makassar. However, the Digital Entrepreneurship Technology (DTE) and Digital Multisided Platform (DMP) factors must continue to develop, which is followed by the development of a digital entrepreneurship platform so that it can add to the expansion of the online market. The government needs to pay attention to policies that will be faced with business changes, namely by providing internet facilities that are smooth and spread across all regions by seeking development in terms of telecommunication infrastructure, developing quality people and realizing a network that is free from interference.
\end{abstract}

Keywords: Millennial Entrepreneur Ecosystem, Digital Entrepreneurship, Covid-19.

\section{INTRODUCTION}

The presence of a generation called generation $\mathrm{Y}$ or millennial generation in Indonesia is due to the development of technology, information and communication. The development of technology, globalization and the flow of information absolutely has a fairly large effect on the life of the nation and state, and the millennial generation does not escape. In its position, the millennial generation is recognized as a generation that is capable of technology in contrast to the previous generation. The birth of the millennial generation emerged in the era of technology which began to enter various elements of people's daily activities and has been able to help in various sectors to fulfill the needs and lifestyles of today's successor which are complex and able to move [1].
Technology assisted marketing tools that are growing today, with easy login facilities to get notifications in a wide and large scope, make it easier for the millennial generation who are in the business world or are entrepreneurship to innovate and change their business ideas to a more modern way. and have access to marketing that is efficient, effective and fast. Starting from a conventional business to a technology-based business [2].

There was an outbreak of Covid-19 in the city of Wuhan, in the Hubei area, China in December 2019 and has been published as a pandemic by various agencies and world organizations such as the WHO so that various regions around the world feel its effects. Indonesia itself, has experienced weaknesses 
and setbacks in various fields, specifically the economy. The location of the business, which is nothing but the main element of the area that drives the economy and finance, also has a big impact [3].

The conditions and the existence of the Covid-19 outbreak are protracted, so inevitably it is necessary to carry out a transformation in the business perspective which is required in almost all business sectors. Not a few millennial generations who become entrepreneurs do their best to get a strategy to survive and advance, namely by innovating and creating a transformation of the way their business works. In developing a business, this generation introduces its production by utilizing technology that is directly connected to its marketing, shows its performance in the midst of an epidemic, utilizes web-based media and is proven to have the possibility to support communication between consumers and the products they offer [4].

It takes a form of entrepreneurial innovation that can change with the approach of advances and technological developments. Then this innovation gave rise to a form of digital-based entrepreneurship. This form of business originates from a combination of digital technology and entrepreneurship which then creates a new phenomenon of characteristics and characteristics in terms of entrepreneurship [5]. Digital entrepreneurship is a composite of the different components of the entrepreneurial and technological aspects. Currently digital entrepreneurship appears in the form of internet applications that are supported by technology, information and communication [6].

In general, entrepreneurial activity is a process of changing or transforming assets and important components of a business into a form of digital platform which is classified as digital entrepreneurship [7]. In digital entrepreneurship, social interaction in the digital environment focuses on using technology in the present moment. Digital entrepreneurship is created by developing a digital ecosystem [8]. In a digital ecosystem, coordination is needed that is closely related to products, services, and locations, so that they can determine the influence of the formation of digitalbased entrepreneurship [9].

In the current situation, the existence of digitalbased technology will have an impact on a new entrepreneur that will be started. The perspective on a technology that is present can be utilized as a capital for cooperation and collective intelligence to form and create entrepreneurial ideas that are stronger and sustainable.
Digital ecosystem models can provide transparent and adaptable knowledge and information that need to be assembled technically, continuously, by grouping, inspired by natural ecosystems [10]. The digital ecosystem is the main thing that must be applied in digital entrepreneurship by millennial business players with an ecosystem work design, which combines library resources on the digital ecosystem and the entrepreneurial ecosystem. The Digital Entrepreneurship Ecosystem (DEE) is a new work plan to direct knowledge about entrepreneurship in the digital era, more specifically digital entrepreneurship on the basis of more digital platforms, institutions and users. Susan, F., \& Acs, ZJ [11]. The digital ecosystem will apply to business if it uses insight management, education and services, social networks. Smith et al [12]. say that the digital ecosystem is a relationship between entrepreneurship and the resources used to obtain the desired results. Characters in digital ecosystem can be achieved through offering design of bidding and bonding and gaining as many connections as possible to gain insight [13].

New insights related to the entrepreneurial ecosystem include an evolutionary approach, social relationships and trait relationships in the entrepreneurial activity process [14]. The concept of entrepreneurial ecosystem activities focuses on entrepreneurial opportunities to track and expand businesses [15]. Entrepreneurship offers conditions for an ecosystem, where a healthy entrepreneurial ecosystem is characterized by the ability of entrepreneur to create, support, and maintain entrepreneurial activities to develop more. In line with the development of digitalization has an impact so that the question arises "what is the role of digital technology in entrepreneurship and the environment?" [16].

Entrepreneurs find that the digital ecosystem has potential not only as a form of business but also as a digital change platform that prepares a business environment for innovators to experiment with ideas and contribute to digital solutions through the terms of cooperation [17].The most important contribution in the design of the digital entrepreneurship ecosystem is to be able to discuss the benefits of technology in general and digital technology in particular. One of the effects of digital technology on the entrepreneurial ecosystem is the occurrence of transaction space from local, global, or more aspects [18].

This study aims to describe the transformation of innovation from conventional millennial entrepreneurs to businesses with digital ecosystems. It is highly expected to be able to increase the expansion of the 
online market and sales. As an effort to achieve a fast digitization situation so that it does not make it difficult for millennial entrepreneurs to start a digital-based business ecosystem, by distributing access evenly through new discoveries to millennial entrepreneurs so that during the current Covid 19 pandemic they can survive in business competition. To maintain a business, millennial entrepreneurs need to have skills in using digital technology in their online business activities in the midst of the Covid 19 virus outbreak.

\section{RESULT AND DISCUSSION}

\subsection{Digital user citizenship or abbreviated (DUC)}

The emergence of digitalization is one of the reasons that have an impact on the transformation of the Makassar City millennial entrepreneurial participation practice model, where the stages and applications have open and free principles in determining roles and participation in order to get many benefits in providing an understanding of entrepreneurship for the general public who carry out business activities in designing digital business ecosystem. The development of a computerized-based millennial business stage is a different option by saving pilot areas. Makassar Regional Government through the ranks of the Provincial Government and SMEs has continued to support computerized changes.

In this way, the COVID-19 pandemic has led to the development of a computerized entrepreneurship system for millennial business visionaries in Makassar City. In this unique situation, advanced business is the type of business that uses the complexities of computerized innovation, two cycles to display goods and administration. In the end, the various organizations that sell their goods on the web, regardless of whether using a site or an application, are remembered for the advanced business domain. The use of web-based business applications and the use of online media in advanced promotions are included in the field of computerized business ventures. Thus, the fate of advanced business ventures can be one of the areas that will make many positive commitments to strengthen the Indonesian economy. This can be followed from work that strengthens data innovation in the business world.

In Makassar City during the COVID-19 pandemic, the development and progress of the computerized world in business was very rapid. Various stages of Indonesian computerization have begun to emerge by offering various kinds of progress to make it easier to do exercises. Starting from online transportation, travel, to internet business organizations, they have also enlivened the computerized economy. "There is a responsibility from the local government and the
Makassar regional government during the COVID-19 pandemic to enable business visionary millennials by planning 10,000 computerization capabilities in South Sulawesi, especially Makassar, for reasons separate from the preparation of human resources," said the Head of Makassar City Hall who had stated to delivering 10 thousand advanced business visionaries. However, with the COVID-19 pandemic that has hit the world, considering that for the city of Makassar, individuals are quick to adjust to new conditions and behaviors. Advanced exercise then, at that point, became the daily routine of individuals who were in a computerized innovative environment. In the current COVID-19 pandemic, the computerization stage has become the right answer to help business people follow the development of their organization.

\subsection{Digital technology entrepreneurship (DTE)}

Starting a Continuing Business is the choice chosen by the millennial generation of Makassar City, especially in startup business ventures to prepare solid business visionaries to build their paying business using innovation. Starting or starting a business digitally, you will thoroughly learn about business forms, methods of creating digital content, publishing or promoting content, digitally, creating websites and digital computerized stores. As a component in a computerized business environment that in clarification combines industry players, who develop applications, as well as other agencies that produce workforce and products related to advanced innovation. Advanced Entrepreneurship Technology will create pioneering developments that can adapt to endless conditions to expand the effectiveness of the stage. Great platform support provides assets that work with pioneering development cycles and reasonable and equitable benefit sharing plan propositions [19] The computerized business environment will take an important part in the transformation into a new, advanced based company.

Advanced innovation, which is essentially emerging in capacity building and data and correspondence innovation (ICT) work, supports business development and empowers the advancement of start-ups. The computerized business visionaries who are currently advanced in Indonesia can be grouped into two classifications, namely [20].

a) A digital platform that upholds Millennial Business visionaries by involving business people, claiming local areas, selling goods, generating fees, and action plans, then, at that time, will share the results as benefits of millennial businessmen in Makassar city

b) A digital platform that creates new action plans, specifically supporting Millennial Business visionaries, but turning into action plans that can support each other. Utilization of the 
computerized stage is seen as the key for millennial businessmen to continue to improve and grow the thinking of organizations and organizations.

Not only millennial business visionaries, application suppliers and engineers will make and develop their goods more amazing on the world's computerized stage. one of the designers of the Advanced Stage application in Indonesia who plays an important role in making a difference for SMEs to survive the Covid-19 pandemic is E-commerce. Exercise businessmen and digital application designers as different specialists at an advanced stage cannot be separated from pioneering development. As a business component, advanced innovation makes it clear that businesspeople, application engineers, and specialists play an important part in making pioneering developments and expanding stage proficiency [21].

Especially in the Indonesian state in the city of Makassar during the covid 19 pandemic, there were several forms of digital platform business that had an influence by achieving very high investment values both with decacorns and unicorns, including Gojek, Grab, Tokopedia, Bukalapak, Halodoc, and Ruangguru [22].Business people have the opportunity to be able to generate maximum profits at a computerized stage, because Makassar city is supported by many accessible clients. the presence of the web and web-based media as an advanced stage which has now become an inseparable part of the lives of many people, online media is a scaffold to blend and fulfill the main goals carefully. This reflects the behavior of individuals in Indonesia which is increasingly encouraging advanced lifestyle [23]. us has assets that work with development interactions. the power of information science, intellectual innovation and the power of making a blend that opens up opportunities for advanced work. In Makassar city, the presence of a decent computerized stage will soon engage millennial businessmen to build their sophisticated goods offerings, provide business meetings, raise salaries.

\subsection{Digital multisided platforms (DMP)}

The computerized multisided platform (DMP) is one example of an action plan that is widely used in businesses today. This action plan can create selfesteem by working with connections between one stage and another, but having the same client or member meeting. According to the Advanced 2021 report, almost all Indonesian web clients or around 98.5 percent watch recordings online consistently. Meanwhile, 74.3 percent of Indonesian web clients also watch web video journals (video blogs) consistently. As far as web speed goes, the normal multipurpose web download speed in Indonesia reaches 17.2 mbps. Meanwhile, the normal fixed broadband web speed in Indonesia is $23.32 \mathrm{mbps}$.
This provides the opportunity for a computerized platform presence with the power of the Web, which has changed the way in which business visionaries in the workforce and product fields are executed and showcased practice by making this new worldview, clearly, a very useful data mechanism for dissecting what needs are widely used by business people. Twenty to thirty years in the city of Makassar have the option to develop their creations with the aim of helping to solve local problems. This way the organization will really want to find new clients more effectively on stage. In addition, the internet can also be used for correspondence which is very important for financial experts. The advanced stage in the computerized complex stage can help make it easier for financial managers to filter and provide all the expected customer needs and desires, in addition, prospective buyers can also search for and get educational items just by reading virtually. world, where during the time spent searching for these items, they would give special encounters to buyers. The computerized stage as a web-based media application delivers everything from SMS to informal communication destinations offering clients to collaborate, socialize, and talk to others. This application means initiating and streaming online data about a client's experience of devouring an item or brand, with the basic point of drawing on the general population. In a business environment, individual contributions can drive the creation of benefits. If the advanced stage can offer the type of assistance that is simple and attractive, it will provide tremendous satisfaction to the buyer $[24,25]$.

\section{CONCLUSION}

The Millennial Entrepreneurship Environment that relies on advanced businesses in Makassar City during the COVID-19 period is developing and continues to grow, which is marked by the presence of various computerized stages that provide and produce progress and can compete at the public and global level. Active biological systems and advanced businesses. Therefore, the Makassar Regional Government urges millennial business visionaries to create a viable and serious biological system, especially to continue to create and survive in the midst of the COVID-19 pandemic.

Looking at the study of the Millenial Entrepreneurial Ecosystem on the millennial business visionaries who created a computerized stage-based environment, it is realized that Digital User Citizenship Condensed does not actually present a computerized environment for millennial business visionaries in the city of Makassar given the limited hard strategies in managing authenticity and standards. social computerized society in the city of Makassar. Meanwhile, the Advanced Innovation Business Venture (DTE) and the Computerized 
Multisided platform (DMP) can provide a solidarity component in realizing a computerized environment as a whole and the millennial pioneering era in particular in Makassar City continuing to make in addition to the development of a computerized based market base and the development of an online market base.

There are several strategies that must be carried out by public authorities and become a test to accelerate organizational change from business people to the advanced foundation of the Makassar millennial era, including fast and impartial web accessibility through structuring a broadcast communication framework, developing quality people and realizing a network that is free from interference.

\section{ACKNOWLEDGMENTS}

We thank the anonymous reviewers who have provided constructive suggestions for improving this article.

\section{REFERENCES}

[1] Kurniati, D. (2021). Eksistensi Generasi Millenial dalam Berwirausaha di Era Digital (Studi Kasus Online Shop Denia Donuts Palembang). Journal Science Innovation and Technology (SINTECH), 2(1), 37-45.

[2] Azzahra, S., Dhewanto11, W., Yunita, F., Rizqi, V. N., \& Suwondo, S. (2021). Women Entrepreneurs in FNB Sector Faces Covid-19 Pandemic. In ECIE 2021 16th European Conference on Innovation and Entrepreneurship Vol 1 (p. 257). Academic Conferences limited

[3] Arianto, B. A. M. B. A. N. G. (2019). Buzzer Media Sosial dan Branding Produk UMKM Daerah Istimewa Yogyakarta. Jurnal UMKM Dewantara, 2(1), 27-46.

[4] Ahmad, M. I. S., Rijal, S., Tahir, M. I. T., \& Hasan, M. (2021, August). Transformasi UMKM Dari Bisnis Konvensional Menjadi Bisnis Online Berbasis Digital di Masa Pandemi COVID-19. In Seminar Nasional Teknologi Pendidikan (Vol. 1, No. 1, pp. 94-104).

[5] Giones, F., \& Brem, A. (2017). Digital technology entrepreneurship: A definition and research agenda. Technology Innovation Management Review, 7(5)

[6] Le Dinh, T., Vu, M. C., \& Ayayi, A. (2018). Towards a living lab for promoting the digital entrepreneurship process. International Journal of Entrepreneurship, 22(1),1-17.
[7] Kraus, S., Palmer, C., Kailer, N., Kallinger, F. L., \& Spitzer, J. (2018). Digital entrepreneurship: A research agenda on new business models for the twenty-first century. International Journal of Entrepreneurial Behavior \& Research.

[8] Davidson, E., \& Vaast, E. (2010, January). Digital entrepreneurship and its sociomaterial enactment. In 2010 43rd Hawaii International Conference on System Sciences (pp. 1-10). IEEE

[9] Kraus, S., Palmer, C., Kailer, N., Kallinger, F. L., \& Spitzer, J. (2018). Digital entrepreneurship: A research agenda on new business models for the twenty-first century. International Journal of Entrepreneurial Behavior \& Research.

[10] Purbasari, R., Muttaqin, Z., \& Sari, D. S. (2021). Digital Entrepreneurship in Pandemic Covid 19 Era: The Digital Entrepreneurial Ecosystem Framework. Review of Integrative Business and Economics Research, 10, 114-135.

[11] Sussan, F., \& Acs, Z. J. (2017). The digital entrepreneurial ecosystem. Small Business Economics, 49(1), 55-73.

[12] Smith, C., Smith, J. B., \& Shaw, E. (2017). Embracing digital networks: Entrepreneurs' social capital online. Journal of Business Venturing, 32(1), 18-34.

[13] Kraus, S., Palmer, C., Kailer, N., Kallinger, F. L., \& Spitzer, J. (2018). Digital entrepreneurship: A research agenda on new business models for the twenty-first century. International Journal of Entrepreneurial Behavior \& Research

[14] Cooke, P. (2016). The virtues of variety in regional innovation systems and entrepreneurial ecosystems. Journal of Open Innovation: Technology, Market, and Complexity, 2(3), 13.

[15] Acs, Z. J., Autio, E., \& Szerb, L. (2014). National systems of entrepreneurship: Measurement issues and policy implications. Research policy, 43(3), 476-494.

[16] Song, A. K. (2019). The Digital Entrepreneurial Ecosystem - a critique and reconfiguration. Small Business Economics, 53(3), 569-590.

[17] Hsieh, Y. J., \& Wu, Y. J. (2019). Entrepreneurship through the platform strategy in the digital era: 
Insights and research opportunities. Computers in Human Behavior, 95, 315-323.

[18] Cavallo, A., Ghezzi, A., \& Balocco, R. (2019). Entrepreneurial ecosystem research: Present debates and future directions. International Entrepreneurship and Management Journal, 15(4), 1291-1321.

[19] Song, A. K. (2019). The Digital Entrepreneurial Ecosystem - a critique and reconfiguration. Small Business Economics, 53(3), $569-590$

[20] Ardiansyah, T. (2020). Model Platform ECommerce Dalam Mendukung Kesuksesan UMKM Di Indonesia. Jurnal Usaha, 1(1), 112.

[21] Song, A. K. (2019). The Digital Entrepreneurial Ecosystem - a critique and reconfiguration. Small Business Economics, 53(3), $569-590$

[22] Purwana, D., Rahmi, R., \& Aditya, S. (2017). Pemanfaatan Digital Marketing Bagi Usaha
Mikro, Kecil, Dan Menengah (UMKM) Di Kelurahan Malaka Sari, Duren Sawit. Jurnal Pemberdayaan Masyarakat Madani (JPMM), 1(1), 1-17.

[23] Purwana, D., Rahmi, R., \& Aditya, S. (2017). Pemanfaatan Digital Marketing Bagi Usaha Mikro, Kecil, Dan Menengah (UMKM) Di Kelurahan Malaka Sari, Duren Sawit. Jurnal Pemberdayaan Masyarakat Madani (JPMM), 1(1), 1-17.

[24] Purwana, D., Rahmi, R., \& Aditya, S. (2017). Pemanfaatan Digital Marketing Bagi Usaha Mikro, Kecil, Dan Menengah (UMKM) Di Kelurahan Malaka Sari, Duren Sawit. Jurnal Pemberdayaan Masyarakat Madani (JPMM), 1(1), 1-17.

[25] Purbasari, R., Muttaqin, Z., \& Sari, D. S. (2021). Identification of Actors and Factors in the Digital Entrepreneurial Ecosystem: The Case of Digital Platform- Based MSMEs in Indonesia. Review of Integrative Business and Economics Research, 10, 164-187. 